TITLE:

\title{
Efficacy of the dual controlled release of HGF and bFGF impregnated with a collagen/gelatin scaffold(Abstract_要旨)
}

\section{$\operatorname{AUTHOR}(\mathrm{S}):$}

Ogino, Shuichi

\section{CITATION:}

Ogino, Shuichi. Efficacy of the dual controlled release of HGF and bFGF impregnated with a collagen/gelatin scaffold. 京都大学, 2018, 博士(医学)

ISSUE DATE:

2018-01-23

URL:

https://doi.org/10.14989/doctor.k20807

\section{RIGHT:}

Final publication is available at

http://dx.doi.org/10.1016/j.jss.2017.08.051

https://www.elsevier.com/about/our-business/policies/sharing 


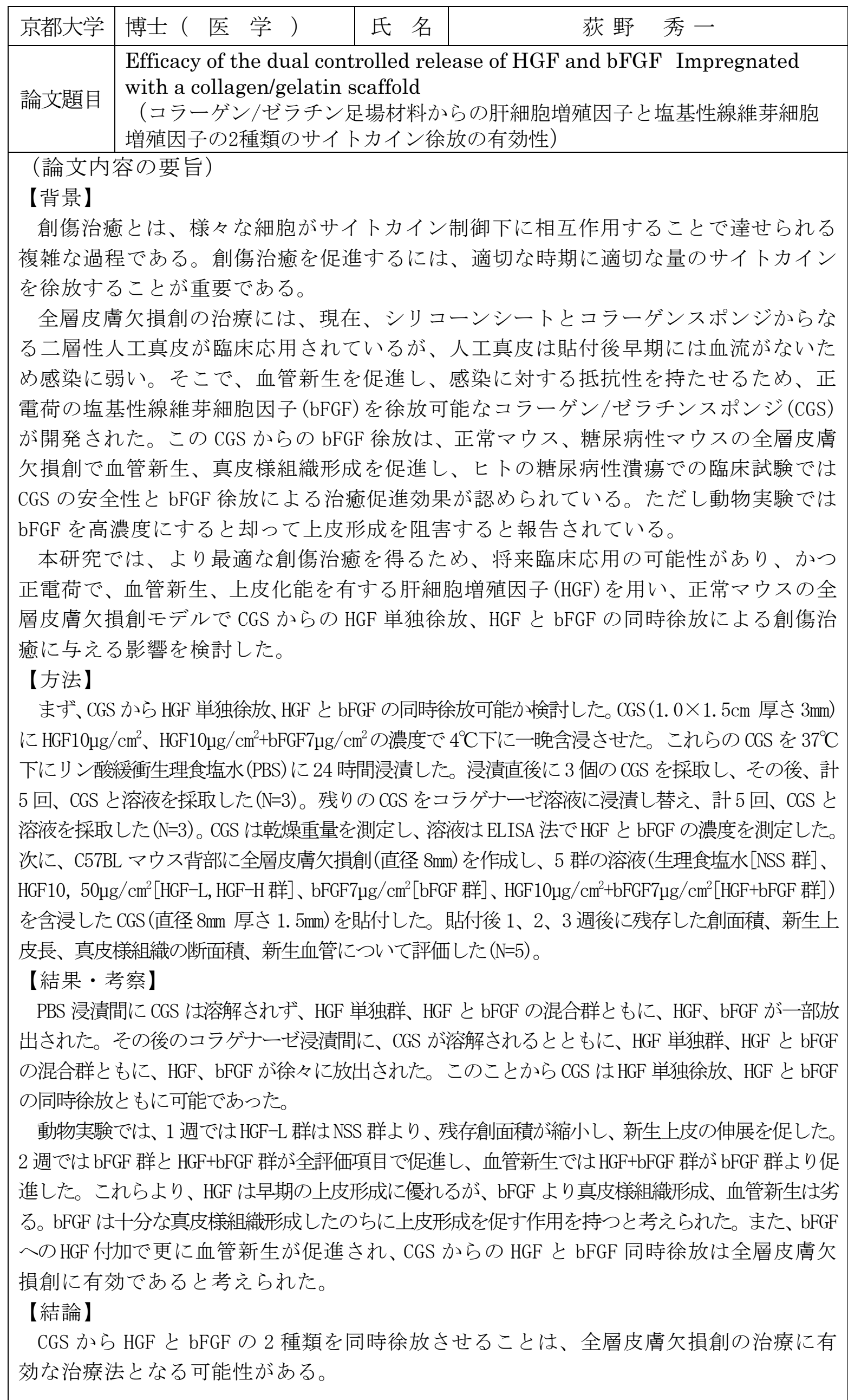

（論文審査の結果の要旨）

【目的】皮膚全層欠損創の治療に用いられている人工真皮（コラーゲンスポンジ：CS）の久点 を克服するために、塩基性線維芽細胞增殖因子(bFGF) を徐放可能な新規人工真皮（コラーゲン/ ゼラチンスポンジ：CGS)が開発され、臨床試験でCGS の安全性および真皮様組織形成と血管新生 の促進効果が認められたが、bFGF の単独使用効果には限界がある。更なる創傷治癒促進を目指し、 肝細胞增殖因子(HGF)を用い、CGS と HGF、bFGF の併用効果を検討した。

【方法】まず、 in vitro でCGS からの HGF と bFGF の徐放を検討した。次いで正常マウス背部 に全層皮膚欠損創を作成し、 5 群の溶液(生理食塩水 $\left[\mathrm{NSS}\right.$ ]、 $\mathrm{HGF} 10 \mathrm{\mu g} / \mathrm{cm}^{2}[\mathrm{HGF}-\mathrm{L}] 、 \mathrm{HGF} 50 \mathrm{\mu g} / \mathrm{cm}^{2}$

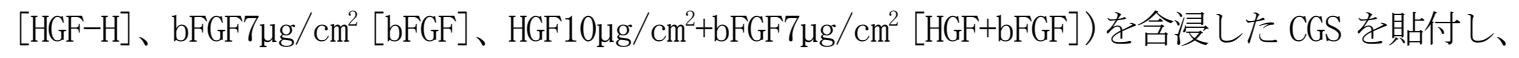
貼付後の創面積、新生上皮長、真皮様組織の断面積、新生血管の数および断面積を評価した。

【結果・考察】CGS からの HGF 単独、HGF と bFGF 同時徐放ともに可能であった。動物実験では、 1 週ではHGF-L 群はNSS 群と比べ、新生上皮の伸展を示した。2 週ではbFGF 含有 2 群が全項目で 促進を示し、血管新生数，断面積では HGF+bFGF 群が bFGF 群と比べ増加した。これらより、HGF は早期の上皮形成に優れることと、 bFGF への HGF 付加で更に血管新生を促進寸ることが明らかに なり、CGS から HGF と bFGF を同時徐放させることは、全層皮膚欠損創の有効な治療法となる可能 性が示された。

以上の研究は新規人工真皮からの肝細胞増殖因子徐放効果の解明に貢献し、新たな創傷治療法 の開発に寄与するところが多い。

したがって、本論文缚士（医学）の学位論文として価值あるものと認める。

なお、本学位授与申請者は、平成 29 年 12 月 26 日実施の論文内容とそれに関連した試 問を受け、合格と認められたものである。 